\title{
Analysis of Heavy Rain and Risk Assessment in the Main Flood Season of the Yangtze River Basin in 2020
}

\author{
Zijie Jiang $^{1,2}$, Xiaoya Wang ${ }^{1,2, *}$, Weiguo Jiang ${ }^{1,2}$, Dabin $\mathrm{Ji}^{3}$
}

\author{
${ }^{1}$ Key Laboratory of Environmental Change and Natural Disaster, Ministry of Education, Beijing Normal University, \\ Faculty of Geographical Sciences, Beijing 100875, China; \\ ${ }^{2}$ Beijing Key Laboratory for Remote Sensing of Environment and Digital Cities, Faculty of Geographical Science, \\ Beijing Normal University, Beijing 100875, China \\ ${ }^{3}$ State Key Laboratory of Remote Sensing Science, Aerospace Information Research Institute, Chinese Academy of \\ Science, Beijing 100101, China \\ *Xiaoya Wang. Email: wxy_seu@163.com
}

\begin{abstract}
Affected by heavy rainfall, the Yangtze River's 2020 floods No. 1 and No. 2 formed in the upper reaches of the Yangtze River on July 2 and 17, respectively. In order to explore the specific change process and impact of this heavy rainfall, this paper uses high-resolution precipitation fusion data, which is based on Himawari-8 stationary meteorological satellite data and GPM-IMERG data generation. And using the data from the ground weather station of the China Meteorological Administration, the analysis of rainfall conditions and the risk assessment of rainstorm disasters in the Yangtze Basin were carried out. The assessment period is the main flood season in 2020, from June 1 to July 19.The main contents and conclusions include: (1) The rainstorm in the Yangtze River Basin mainly affected the middle and lower reaches of the Yangtze River, with northeast Hunan, southern Hubei, Jiangxi and southern Anhui seriously affected; the prefecture level cities mainly affected were Yiyang and Yueyang in Hunan, Jingzhou, Wuhan and Ezhou in Hubei, Shangrao, Jiujiang, Nanchang in Jiangxi, Anqing and Xuancheng in Anhui; the main affected basins were Poyang Lake ,Taihu Lake and Dongting Lake. Among them, Poyang Lake Basin is the most seriously affected. (2) Heavy rainfall mainly occurred in late June and early July, and the accumulated rainfall exceeded $1000 \mathrm{~mm}$ every 10 days. (3) Compared with the rainfall of the Yangtze River Basin in 1998, it is found that the distribution range of heavy rainfall in 2020 is less than that in the same period of 1998, but the rainfall is significantly higher than that in the same period of 1998, and the seriously affected Poyang Lake Basin exceeds the historical value of the same period. (4) Most areas in the lower reaches of the Yangtze River Basin are high risk areas. Dongting Lake Basin, Poyang Lake Basin and Taihu Lake Basin are high risk areas.
\end{abstract}

Keywords: Floods in the Yangtze River Basin, rainstorm disasters, risk analysis, dynamic assessment, Poyang Lake Basin

\section{长江流域 2020 年主汛期 暴雨降雨量及危险性评估分析 \\ 蒋梓杰 ${ }^{1,2}$, 王晓雅 ${ }^{1,2, *}$, 蒋卫国 ${ }^{1,2, *}$ ，姬大涁 ${ }^{3}$}

\footnotetext{
${ }^{1}$ 环境演变与自然灾害教育部重点实验室 北京师范大学 地理科学学部 北京 100875

${ }^{2}$ 环境遥感与数字城市北京市重点实验室 北京师范大学 地理科学学部 北京 100875

3 遥感科学国家重点实验室, 中国科学院空天信息创新研究院 北京 100101

*王晓雅. 电子邮箱: Wxy_seu@163. com
} 


\section{摘要}

受强降雨影响，长江 2020 年第 $1 、 2$ 号洪水分别于 7 月 2 日、 17 日在长江上游形成。为探究本次强降雨的具 体变化过程及影响, 本文基于葵花 8 号静止气象卫星数据以及 GPM-IMERG 数据生产高分辨率降水融合数据及 中国气象局地面气象站点数据对长江流域内展开了的降雨情况分析及暴雨灾害危险性评估。评估时间为 2020 年主汛期, 即 6 月 1 日至 7 月 19 日。主要内容和结论包括: (1) 本次长江流域暴雨主要影响的地区集中在 长江中下游, 湖南东北部、湖北南部、江西全境及安徽南部等地受影响较重; 主要影响的地级市有湖南益阳、 岳阳, 湖北荆州、武汉、鄂州, 江西上饶、九江、南昌, 安徽安庆、宣城; 主要影响的流域为鄱阳湖、洞庭 湖、太湖等重点湖泊流域, 其中鄱阳湖流域受影响最为严重。（2）强降雨集中出现在 6 月下旬及 7 月上旬, 逐 10 日累积降雨量突破 1000mm。（3）与 1998 年长江流域降雨整体比较发现，2020 年的强降雨分布范围小 于 1998 年同期，但降雨量明显多于 1998 年同期，其中受灾严重的鄱阳湖流域超出历史同期值。（4）长江流 域下游普遍大部分地区为高危险区，洞庭湖流域、鄱阳湖流域、太湖流域危险性高。

关键字：长江流域洪水，暴雨灾害，危险性分析，动态评估，鄱阳湖流域

\section{1. 引言}

洪涝灾害是全球发生最为频繁、影响范围最大、 受灾程度最严重的自然灾害之一, 洪水灾害的成因 主要包括人为因素和自然因素, 诸多因素中, 暴雨 是直接引发洪水灾害的直接原因 ${ }^{[1]}$ 。近 30 年平均每 年发生 131 次、受影响人口超 1 亿人、经济损失达 237 亿美元, 我国是洪水灾害频发国家, 近 30 年累 计发生 200 余次 ${ }^{[2]}$, 对暴雨灾害的动态监测可为我国 灾害风险管理提供重要技术支撑。

目前, 对暴雨灾害可通过实地勘察及遥感监测等 两种主流方法进行监测与评估 ${ }^{[3]}$ 。实地勘察如水文 站点观测、实地人员测绘等方式获取灾害的过程及 受损情况, 该方法准确度较高, 但数据获取过程不 易操作、需要较多的时间成本 ${ }^{[4]}$; 遥感监测则是基 于遥感影像及产品, 近些年遥感信息技术的方法为 灾害监测提供了有利条件 ${ }^{[5]}$, 结合地理信息和遥感 技术的暴雨灾害风险评估方法成为当下主流趋势 ${ }^{[6][7]}$ 。 蒋新宇和饶品增等学者采用了遥感数据结合经济和 农作物分布数据的方式, 评估暴雨洪涝的灾害损失 和风险情况 ${ }^{[8]}[9]$ 。然而多数研究在灾害评估时, 未考 虑致灾因子的危险性和承灾体的脆弱性等因素, 因 此引入综合考虑多种因子的暴雨灾害风险评估指标 体系有助于评估结果的准确合理。谢五三等采用了 逐小时降雨数据、地形、土地利用及土壤数据建立 评估了暴雨灾害下大通河流域的淹没情景 ${ }^{[10]}$ 。盛绍 学等综合考虑了致灾因子 (降水量) 及承灾体（径 流量、地形、河网密度、土地利用、人口、经济) 的特性, 评估了沿淮湖泊洼地区域的暴雨灾害危险 性 ${ }^{[11]}$ 。石涛等在评估芜湖市的暴雨洪涝风险时, 便 以致灾、孕灾、承灾和抗灾 4 个风险评价因子为基 数据基于葵花 8 号静止气象卫星数据以及 GPM-IMERG (Near Real Time-NRT) 数据生产的高分辨率降水
础 ${ }^{[12]}$ 。通过文献梳理可以发现, 降雨量及下垫面等 因子是暴雨灾害危险性评估体系中不可或缺的指标 [13]。

本文选取 2020 年长江流域主汛期即 6 月 1 日-7 月 19 日的时间范围, 以逐 10 日、逐月时间尺度上 探究降雨变化过程, 并分析影响严重的鄱阳湖流域 情况, 对比分析 1998 年长江流域特大洪水同期降雨, 利用指标法评估暴雨灾害危险程度并探讨其变化规 律, 对此次长江流域洪水有较为清晰的认识, 为案 例研究提供方法与经验。

\section{2. 研究区概况}

长江流域面积为 180 万平方公里, 西高东低, 气候条件、地形条件变化大。2020 年 6-7 月, 长江 流域降雨量较多年同期均值偏多, 特别是中下游干 流区域的降雨量多一倍以上。受强降雨影响, 长江 2020 年第 $1 、 2$ 号洪水分别于 7 月 2 日、 17 日在长江 上游形成, 长江中下游地区发生区域性大洪水。

“洞庭四水”、“鄱阳五河” 合成流量较同期均值 偏多, 鄱阳湖流域发生超历史大洪水。其中, 湖南、 湖北、江西、安徽等省份受洪水影响巨大。

\section{3. 数据源与研究方法}

\section{1 数据}

\section{1 .1 卫星遥感数据}

本文采用的卫星遥感数据是高分辨率降水融合 数据, 时间范围为 2020 年 6 月 1 日至 7 月 19 日。该 融合数据, 产品的时间分辨率为 $0.5 \mathrm{~h}$, 空间分辨率 为 $0.02^{\circ}$ (约 $2 \mathrm{~km}$ )。其中, 葵花 8 号数据的时间 
分辨率为 10 分钟, 可见光空间分辨率为 $1 \mathrm{~km}$, 红外 波段为 $2 \mathrm{~km}$; GPM-IMERG 近实时降水融合数据是 NASA 在 TRMM-3B42 的基础上发展的新一代多源降水融合 产品, 空间分辨率 $0.1^{\circ}$, 时间分辨率为 30 分钟。

\section{1 .2 气象站点数据}

为评估此次 2020 年长江流域暴雨降雨量在不同 区域的表现, 及对比分析 1998 年长江流域洪水的历 史同期降雨量及危险性，本文采用了来自国家气象 中心的气象站点数据, 时间分辨率为 $1 \mathrm{~h}$, 长江流域 范围内包含站点共 644 个。重点子流域即鄱阳湖流 域包含 10 个站点, 洞庭湖流域包含 14 个站点, 太 湖流域包含 11 个站点。经处理合成为日降雨强度和 时段总降雨量数据。

\subsection{3 孕灾环境数据}

孕灾环境数据主要用于计算暴雨灾害危险性, 数据包括矢量的河网分布数据, 及栅格的土地利用、 土壤分类、DEM 高程数据, 三者均为 $1 \mathrm{~km}$ 空间分辨率。

\section{2 研究方法}

\subsection{1 降雨量信息提取}

降雨量信息提取分为两部分内容：降雨空间分 布信息提取及降雨量时序信息提取。对于对比分析 的 1998 年长江流域暴雨灾情采用的是气象站点数据, 对不同站点进行空间插值, 得到长江流域 6 月与 7 月 的降雨分布图。对于 2020 年长江流域暴雨雨情分析, 空间分布信息提取采用时间分辨率为 30 分钟、空间 分辨率为 $0.02^{\circ}$ 的高分辨率降水融合数据, 共计 2352 景影像。对 $0.5 \mathrm{~h}$ 时间分辨率的数据做地图代数 运算, 得到日降雨数据。

$$
\operatorname{Rain}_{\text {day }}=\sum_{\mathrm{i}=1}^{\mathrm{n}} \text { rain }_{0.5 \mathrm{~h}}
$$

时序信息提取方面, 是对研究区内所有时段内 的日降雨量影像逐像元提取降雨量信息, 得到不同 时段不同区域的雨情动态变化结果。

\section{2 .2 暴雨灾害危险性评估}

暴雨灾害危险性评估需要考虑致灾因子（降雨 量）及孕灾环境（土地利用/土壤分类/高程/河网分 布) 等因素。不同土地利用类型的径流系数各不相 同, 径流系数越大, 土壤黏性越大、坡度越小、距 离河流越近, 都会使暴雨灾害危险性增高。因此,
计算暴雨灾害危险性是, 要对不同影响因素赋予不 同权重，以评估灾害危险性 ${ }^{[14]}$ 。具体公式如下：

$$
\text { Hazard }=\omega_{1} \mathrm{R}+\omega_{2} \mathrm{I}+\omega_{3} \mathrm{~S} 1+\omega_{4} \mathrm{~L}+\omega_{5} \mathrm{D}+\omega_{6} \mathrm{So}
$$

式中, $R$ 表示某时段内总降雨量; $I$ 为降雨强度; $S 1$ 为 DEM 计算的坡度; $L$ 为土地利用类型; $D$ 表示与 河流的距离; So 为土壤类型。 $\omega_{i}(\mathrm{i}=1 \cdots 6)$ 为不同因 素的权重, 权重数值采用层次分析法得到, 权重值 分别为: $0.39 、 0.39 、 0.1 、 0.06 、 0.04 、 0.02$ 。输 入的各个参数值进行标准化, 使各参数指标值的范 围为 $0-1$, 而后将计算得到的危险性等间隔分为四个 等级, 分别为高危险区 (0.75-1) 、中危险区 (0.5-0.75) 、低危险区（0.25-0.5）、无危险区 $(0-0.25)$ 。

\section{4. 结果分析}

\section{1 暴雨情况分析}

\subsection{1 长江流域逐10日降雨变化情况}

基于高分辨率降水融合的遥感反演数据, 得到 6 月 1 日-7 月 19 日逐 10 日降雨量空间分布情况。

6 月 1 日-10日, 强降雨主要集中在江西大部分 及湖南中东部地区, 江西北部环鄱阳湖地区降雨峰 值达到 $922.2 \mathrm{~mm}$ 。6 月 11 日-20日, 强降雨集中出现 在贵州北部、重庆东南部、湖北东南部、安徽南部 和江苏南部, 最高峰值达到 $814.9 \mathrm{~mm}$ （图 1）。

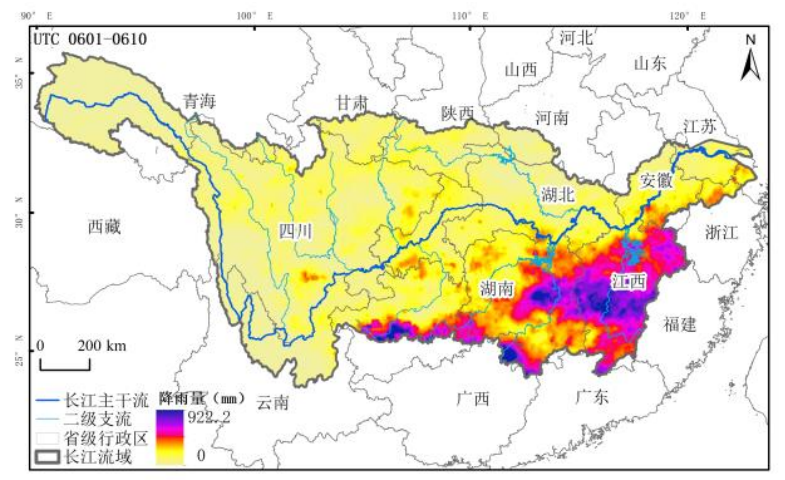




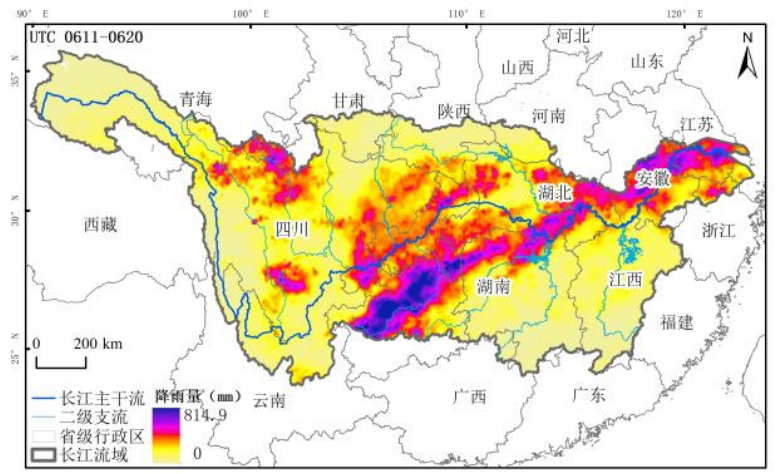

图 16 月 1-10日及 11-20 日降雨量分布图

6 月 21 日-6 月 30 日，长江流域中下游普遍多 雨, 多地出现强降雨。强降雨主要集中在贵州西北 部、重庆西南部、湖南西南部、江西中部、湖北东 部、安徽西南部, 峰值降雨量达到 $876.7 \mathrm{~mm}$ 。 7 月 1 日-7 月 10 日, 强降雨转向长江流域下游, 且雨量加 剧。在湖北东部、江西全境、安徽西南及浙江北部, 形成大范围强降雨。其中江西东北部雨情形势最为 严峻，该区域降雨量超过 $1000 \mathrm{~mm}$ （图 2）。
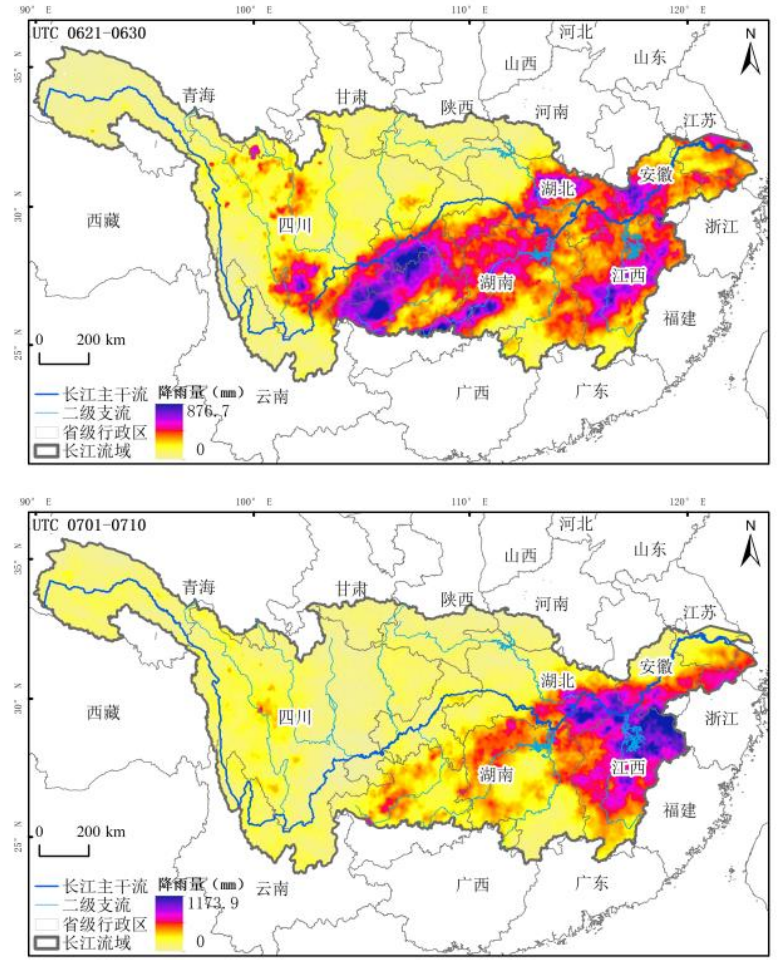

图 26 月 21-30日及 7 月 1-10 日降雨量分布图

7 月 10 日-7 月 19 日, 强降雨转向安徽、江苏 及上海境内。该区域降雨量自 7 月以来持续增多,
且范围持续加大, 降雨峰值达到 $958.3 \mathrm{~mm}$ 。四川东南 部及重庆中部部分地区出现较强降雨（图 3）。

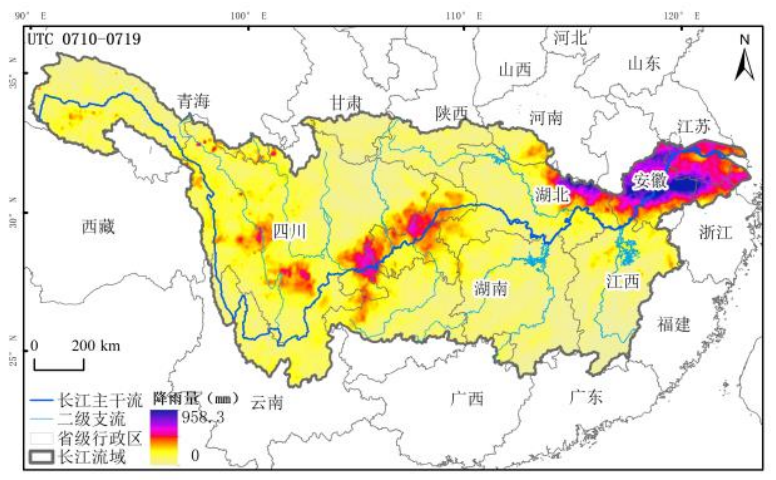

图 37 月 10-19 日降雨量分布图

\subsection{2 长江流域月降雨情况}

6 月 1 日-30日, 长江流域上游青海、四川等地 降雨较少, 累积降雨量低于 $500 \mathrm{~mm}$ 。流域中下游形 势严峻, 重庆、贵州北部、湖北中南部、湖南西北 部、安徽东南部、江西北部等地区出现强降雨, 局 部地区雨情严重, 如, 湖北荆州、江西吉安、安徽 安庆、湖南常德等市, 降雨量超过 $1000 \mathrm{~mm}$ 。 7 月 1 日-19 日, 流域内强降雨主要集中在下游（图 4）。 7 月 2 日, 长江一号洪水形成后, 湖北中东部、江 西东北部、安徽南部及江苏南部出现强降雨。局部 地区如湖北武汉、鄂州, 江西上饶、九江、南昌, 贵州毕节, 安徽安庆、芜湖、宣城, 江苏苏州, 浙 江嘉兴等地 20 日累积降雨量超过 $750 \mathrm{~mm}$, 江西九 江、上饶局地累积降雨量突破 $1000 \mathrm{~mm}$ 。

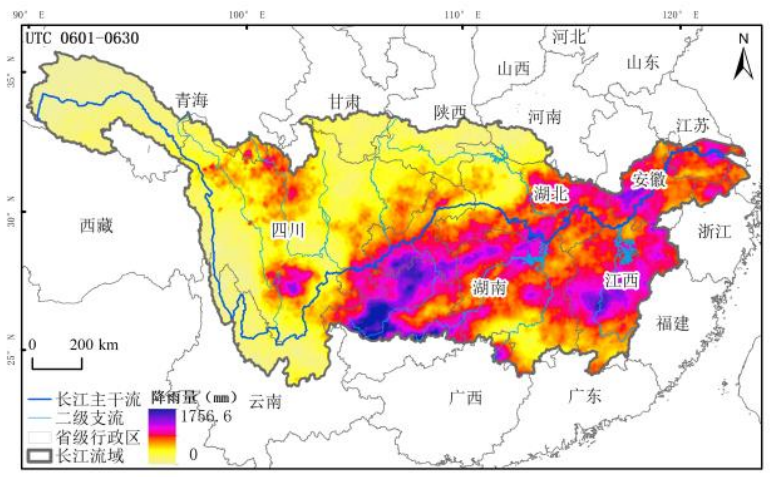




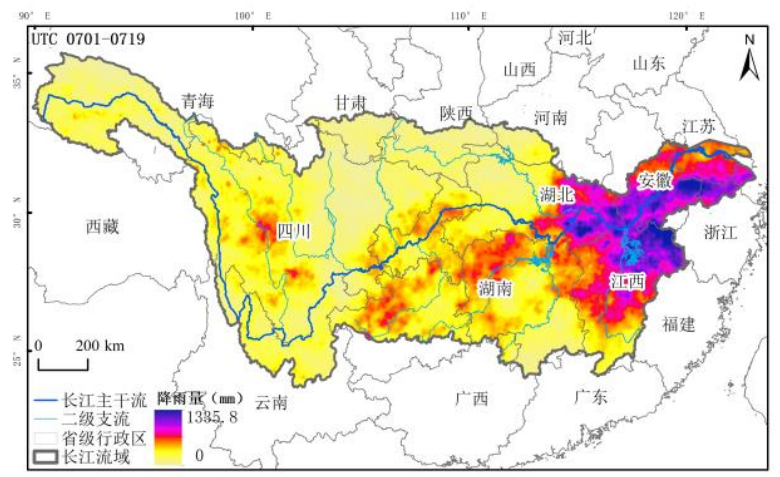

图 42020 年 6 月及 7 月降雨量分布图

\subsection{3 鄱阳湖流域降雨分布情况}

利用 6 月 1 日-7 月 19 日长江流域遥感反演降水 数据, 结合不同省市的站点数据, 从日降雨尺度分 析此次长江流域的降雨变化过程。

选取鄱阳湖区周围余干、波阳、进贤、湖口、 德安、南昌等 9 个站点, 分析其雨量变化。鄱阳湖 湖区 6 月降雨量较少, 除德安、波阳在 6 月上旬雨 量达到大暴雨级别外, 其余站点, 普遍维持在中雨 及大雨级别。自 7 月 10 日以来, 9 个站点均出现强 降雨情况, 雨量持续性增强, 在 7 月 17 日, 多个站 点雨量值突破 $250 \mathrm{~mm}$, 达到特大暴雨级别 (图 5)。
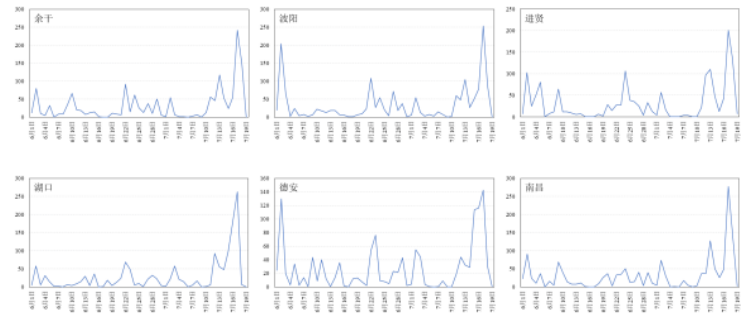

图 52020 年鄱阳湖区降雨量变化

\section{1 .4 与 1998 年长江流域降雨量对比分析}

（1）月降雨对比分析

利用中国气象局的地面气象站点数据, 通过空 间插值得到 1998 年 6 月、 7 月的月降雨量分布图。 1998 年长江流域洪水总体呈现降雨雨量大、涉及范 围广、持续时间长。1998 年 6 月，暴雨主要发生在 长江中下游江南中北部地区。7 月, 主要雨区位于长 江上游一带 (图 6)。
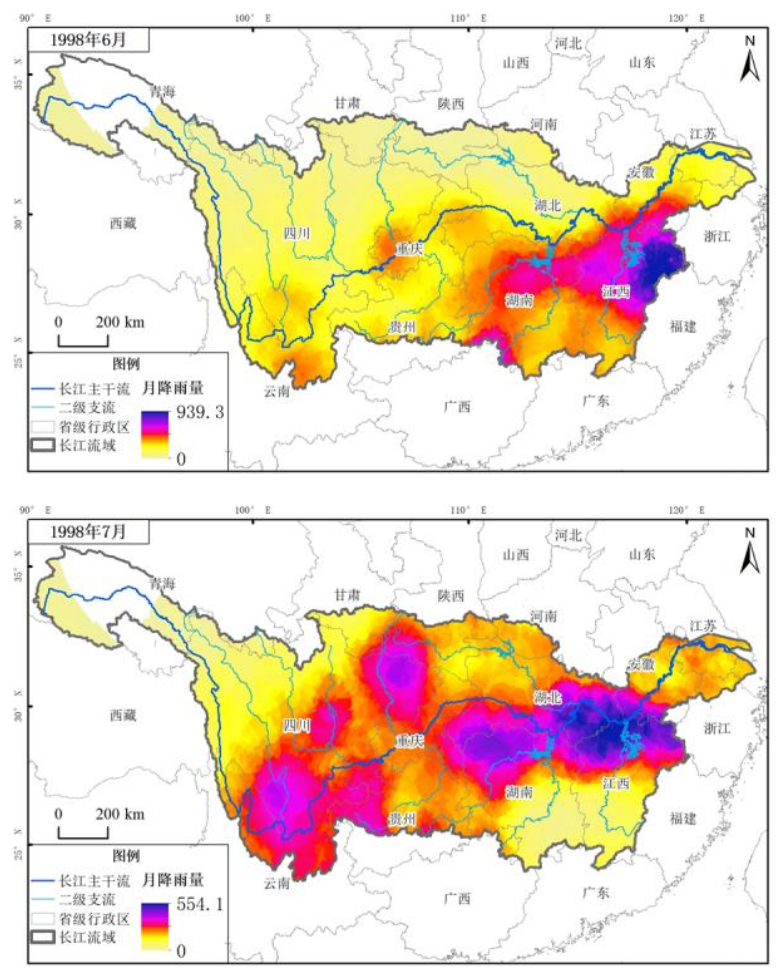

图 61998 年洪水 6 月及 7 月累积降雨量分布

从雨量大小上, 1998 年月最大降雨出现在 6 月, 峰值为 $939.3 \mathrm{~mm}, 7$ 月为 $554.1 \mathrm{~mm}$ 。而 2020 年月降雨, 6 月份、 7 月 1 日-19 日降雨峰值超过 $1000 \mathrm{~mm}$ 。整体 比较发现， 2020 年的降雨量明显多于 1998 年同期。

\section{（2）环鄱阳湖降雨对比分析}

统计 1998 年 6、7 月环鄱阳湖湖区站点降雨数 据发现，1998 年鄱阳湖流域在 6 月 12-26 日， 7 月 16 日-7 月 31 日时间段内, 降雨量均达到大雨及暴 雨级别, 鄱阳湖流域出现长时间的强降雨。2020 年 鄱阳湖降雨主要出现在 7 月 10 日之后，但 7 月中旬 降雨量达到特大暴雨级别, 超过 1998 年同期降雨量 (图 7)。

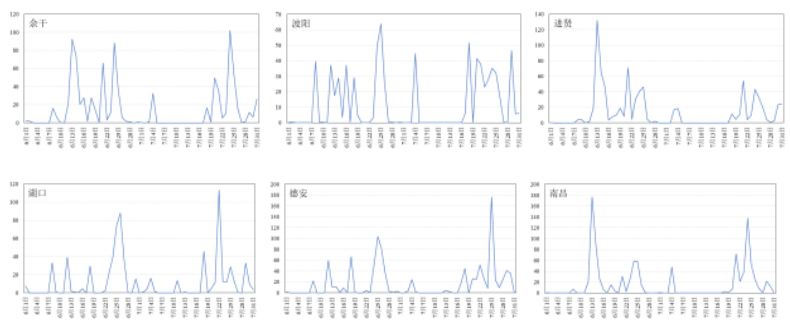

图 71998 年鄱阳湖降雨量变化 


\section{2 暴雨灾害动态危险性分析}

综合考虑长江流域 6 月 1 日-7 月 19 日的日降雨 量强度、不同区域的暴雨天数, 并结合孕灾环境数 据计算其暴雨灾害危险性，得到 6 月 1 日-7月 19 日 逐 10 日暴雨灾害动态危险性分布情况。

6 月 1 日-10日, 长江流域下游普遍大部分地区 为高危险区, 包括江西及湖南东北部地区。6 月 11 日-6月 20 日, 长江流域中下游危险性均较高, 其中 洞庭湖流域、湖北东部、江西北部、安徽南部、江 苏南部、浙江北部及上海均为高危险区（图 8）。
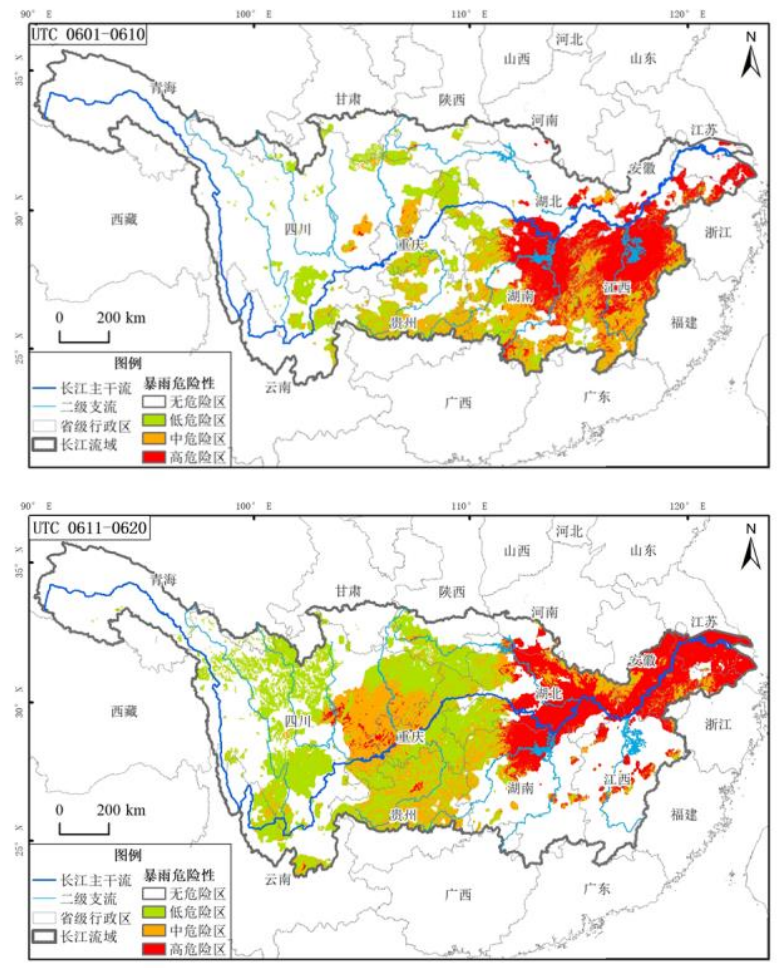

图 8 长江流域 6 月 1 日-6 月 20 逐 10 日暴雨灾害 危险性分布

6 月 21 日- 30 日及 7 月 1 日- -10 日, 危险区范围 较 6 月中上旬明显扩大, 湖南张家界及湖北荆州以 东区域几近都成为中高危险区，洞庭湖流域、鄱阳 湖流域、太湖流域危险性高（图 9）。
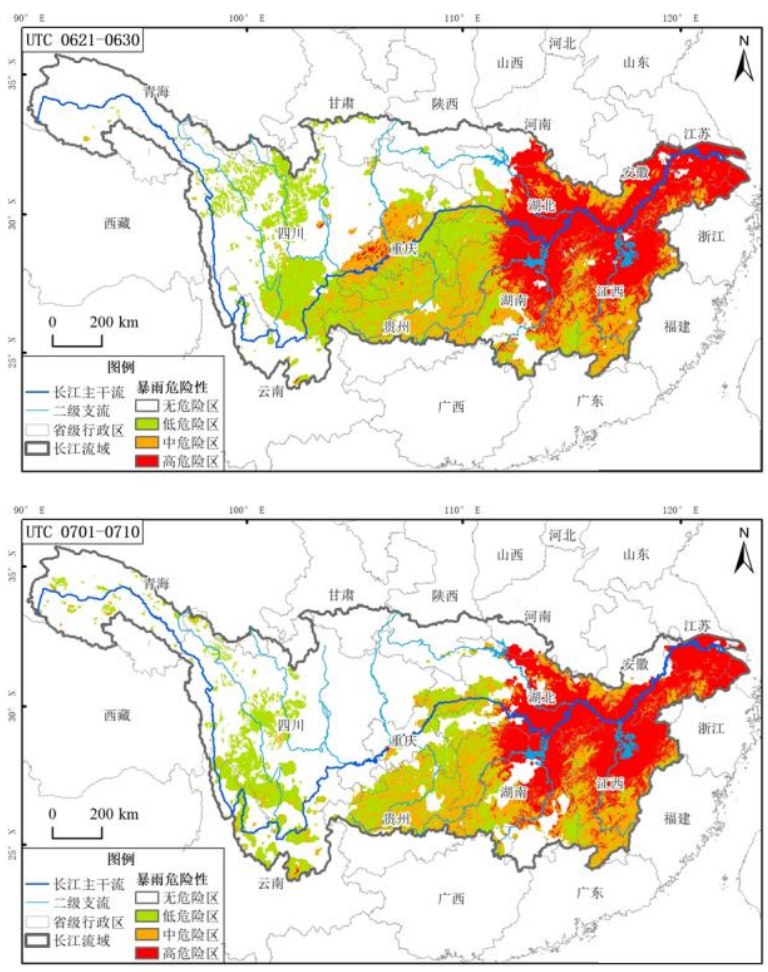

图 9 长江流域 6 月 21 日-7 月 10 日逐 10 日暴雨灾 害危险性分布

7 月 10 日-19 日, 危险区范围有所缩小。高危 险区范围显著减少但有向东北方向转移的趋势。江 西省境内风险区减少，但鄱阳湖流域依然为高危险 区域。湖北东北部, 安徽南部及江苏南部及上海危 险性较高（图 10）。

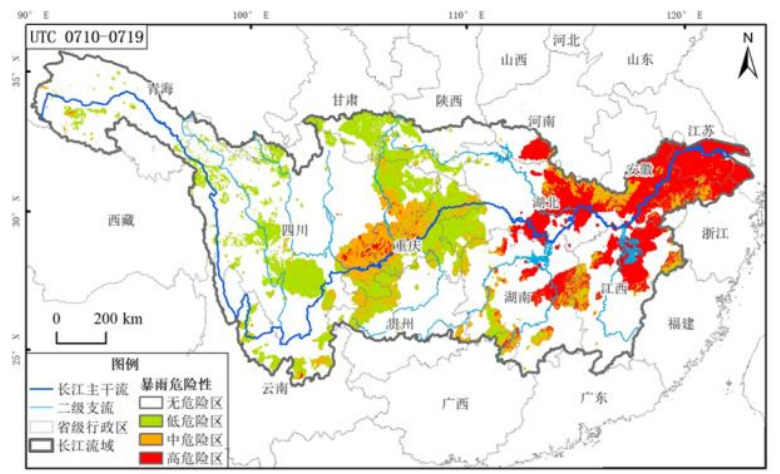

图 10 长江流域 7 月 10 日-7 月 19 暴雨灾害危险性 分布 


\section{5. 结论}

本文以 2020 年长江流域主汛期 1 号、2 号洪水 为例, 从日、月、往年同期等角度分析降雨量的变 化过程, 并结合孕灾环境数据, 评估此次长江流域 洪水事件的暴雨灾害危险性及其动态变化。通过本 文的初步研究发现: (1) 本次长江流域暴雨主要影 响长江中下游区域, 其中湖南东北部、湖北南部、 江西及安徽南部受影响较大; 主要影响的地级市有 湖南益阳、岳阳, 湖北荆州、武汉、鄂州, 江西上 饶、九江、南昌, 安徽安庆、宣城; 主要影响的流 域为鄱阳湖、洞庭湖、太湖等重点湖泊流域, 其中 鄱阳湖流域受影响最为严重。（2）强降雨集中出现 在 6 月下旬及 7 月上旬, 逐 10 日累积降雨量突破 $1000 \mathrm{~mm}$ 。（3）与 1998 年长江流域降雨整体比较发 现, 2020 年的强降雨分布范围小于 1998 年同期, 但 降雨量明显多于 1998 年同期, 其中受灾严重的鄱阳 湖流域超出历史同期值。（4）评估此次事件的暴雨 灾害危险性, 长江流域下游大部分地区暴雨灾害危 险性高, 其中三大重点流域即洞庭湖流域、鄱阳湖 流域、太湖流域危险性均高。

\section{致谢}

本文由国家重点研发计划 “ ‘一带一路” 重特大气 象水文灾害协同监测应急响应关键技术研究及示 范” 课题（2017YFB0504105）与 “重特大灾害应急 评估与动态决策支持关键技术” 课题

（2017YFB0504102）资助。

\section{参考文献}

[1] 蒋卫国, 李京, 陈云浩等. 区域洪水灾害风险评估 体系 (I) - - 原理与方法 $[\mathrm{J}]$. 自然灾害学 报, 2008 .

[2] Jiang Zijie, Jiang Weiguo, Wu Jianjun, Zhou Hongmin. Typical case dataset of major global flood disasters (2018.01-2018.12). National Tibetan Plateau Data Center, 2019. doi: 10.11888/Disas.tpdc.270209.

[3] 陈秀万. 洪涝灾害损失评估系统一一遥感与 GIS 技术应用研究. 北京: 中国水利水电出版 社, $1999,23^{\sim} 44$.

[4] 蒋卫国, 李京, 武建军等. 区域洪水灾害风险评估 体系 ( II ) 一一模型与应用 $[\mathrm{J}]$. 自然灾害学 报, 2008, 17 (6) : 105-105.
[5] Deng, Y.; Jiang, W. G.; Tang, Z. H.; Ling, Z. Y.; Wu, Z. F. Long-Term Changes of Open-Surface Water Bodies in the Yangtze River Basin Based on the Google Earth Engine Cloud Platform. Remote Sens. 2019, 11, (19), 22.

[6] 饶品增, 蒋卫国, 贾凯等. 2013 年黑龙江省洪水对 植被影响评估 [J]. 灾害学, 2017, 032 (4) : 195201.

[7] 蒋卫国, 盛绍学, 朱晓华等. 区域洪水灾害风险格 局演变分析一一以马来西亚吉兰丹州为例 $[\mathrm{J}]$. 地理研究, 2008, 3 (27).

[8] 蒋新宇, 范久波, 张继权等. 基于 GIS 的松花江干 流暴雨洪涝灾害风险评估 $[\mathrm{J}]$. 灾害 学, 2009, 24 (003) :51-56.

[9] 饶品增, 蒋卫国, 王晓雅等. 基于 MODIS 数据的洪 涝灾害分析研究——以 2017 年洞庭湖区洪水为 例 [J]. 灾害学, 2019, 034 (001) :203-207.

[10] 谢五三, 田红, 卢燕宇等基于 Flood Area 模型的 大通河流域暴雨洪涝灾害风险评估 $[\mathrm{J}]$. 暴雨灾 害, 2015, 34(04) :384-387.

[11] 盛绍学, 石否, 刘家福等. 沿淮湖泊洼地区域暴雨 洪涝风险评估 $[J]$. 地理研究, 2010 (03) : 416-422.

[12] 石涛, 谢五三, 张丽等. 暴雨洪涝风险评估的 GIS 和空间化应用一一以芜湖市为例 $[J]$. 自然灾害 学报, 2015, 024(005) : 169-176.

[13] 蒋卫国. 基于遥感与 GIS 的洪水灾害风险模糊评 估及其演变驱动机制研究. 北京师范大学博士论 文, 2006. 16〜99.

[14] 王晓雅, 蒋卫国, 邓越等. “山竹”台风影响地区的 小时降雨动态变化及危险性动态评估 $[\mathrm{J}]$. 灾害 学, 2019 (3) :202-208. 